\title{
Consumtive Behavior: Mental Accounting and Retention-Time Toward
}

\author{
Sudarman \\ High School of Economic Aka Semarang \\ E-mail: sudarman_aji@yahoo.co.id \\ Septian Yudha Kusuma \\ High School of Economic Aka Semarang \\ E-mail: yudhakusuma@gmail.com
}

Received: Oct. 25, 2018 Accepted: Nov. 15, 2018 Online published: Nov. 27, 2018

doi:10.5296/ijhrs.v8i4.13824 URL: https://doi.org/10.5296/ijhrs.v8i4.13824

\begin{abstract}
This research has purpose to find out the influences of mental accounting, a behavior toward money called power-prestige and retention-time will affect toward consumptive behavior. The sample are 36 employess of Handoko hadiprasetyo Tax Consultant Office Semarang. The data are gained through questionnaires. To analyze the data, multiple regression is used. The findings show there is significant relationship between mental accounting and power-prestige toward consumptive behavior. Meanwhile, retention-time does not affect significantly toward the behavior.
\end{abstract}

Keywords: consumptive behavior, mental accounting, power-prestige, and retention-time

\section{Introduction}

Human nature tends to be consumptive, meaning humans will always consume products or services all time. This behavior emerges due to support their various needs and to follow the current growing trend in market. The decision to buy is not only something planned but also the unplanned. Decision to buy something unplanned, called as impulsive buying, means spending uncontrollable amount of money or buying unnecessary goods. The unplanned purchased goods are mostly cheap and unexpected products.

This behavior, according to Sumartono (2002), is not based on rational consideration but due to the existence of irrational stage desire. In this level, someone may buy goods because the 
goods are branded or newly released and trendier. It is all because of the motivation of the buyers to level up their status in their environment without considering the benefit of the goods.

In deciding individual finance is affected by psychological factors. One of them is mental accounting aspect, a phenomenon of finance based on behavior, initially stated by Thaler (1980), a professor of Chicago School. He argues someone creates a mental accounting system in similar ways to organization managing its accounting system to organize and manage financial decision. Mental accounting refers to behavior or reasons of someone in which having tendency to group and treat money in different ways compared to the others based on where the money from. As for example, money from an individual's earning (daily or monthly) will be treated differently to money gained from bonus, gift, or extra incomes. Earnings from bonus or other extra incomes will be considered as additional fortune so it will be easy for them to spend or to invent with high risks. Ishakawa and Ueda in Damayanti and Supramono (2011) empirically proved that in Japan there are different marginal propensities to consume (MPC) between earnings from regular incomes or salary to bonus. By grouping differently based on the sources and the purpose to spend, someone tends to be consumptive to spend the money earned from bonus or other extra incomes. It aligns to Chatterjee, Heath, and Min (1009) arguing mental accounting may inappropriately influence financial decision.

An individual's money attitude is also affected by consumptive behavior because the money earned or had is not only to shop but a certain judgment toward the money also occurs. An individual's point of view toward money is a power and a success for him, stated in Yamauchi and Templer (1982). Power-prestige explains money is a symbol of power and domination (Yamauhchi and Templer, 1982). It insists people to compete in achieving success and acknowledgement from surrounding society. Through money, someone wants to be acknowledged. It can be seen from an individual's socialization and appearance because he wants to be acknowledged. Therefore, sometimes it leads to consumptive behavior to buy luxurious goods without considering the benefits. Power-prestige reflects negative dimension of someone's attitude toward money.

It is different to Retention-time referring to attitudes of spending money by having planned (Yamauchi and Templer, 1982). It is a planning to use the money and to buy goods in which must be well planned first. According to Setyawan (2011), retention-time is a psychological attitude referring to an attitude in which someone does not want to spend his money. To spend his money, he will be very careful and must be planned so that the money will bring benefit. Retention-time reflects positive dimension of someone's attitude toward money.

Fromt preliminary research findings, it can be concluded the empolyees of tax consultant office group their incomes based on their sources and the purpose. Therefore, it indicates the occurence of mental accounting. There is a difference in money attitude so there is a difference attitude in spending the money. By observing their money attitude of the employees with tendency to be consumptive. The employees often struggle to save their outcome in their life but it is difficult to save or even they experience financial problem.

The behavior to group based on the source does not fit to money value expected utility theory, 
stating that the value of money is interchangeable or known as fungibility. To take decision, money from bonus with amount Rp. 1000,- or coming from salary with amount Rp. 1000,should have same values. By the existence of treatment and attitude toward money which lead to consumptive attitude found in preliminary research, the researchers were intertested to find out whether the phenomenon also occurs for all employees or not, and what factors affect it. Thus, this research is given title: The Influences of Mental Accounting, Power-Prestige andRetention-Time Toward Consumtive Behavior (A study done toward KKP Handoko Adiprasetyo Semarang Employees).

According to the explanation and the backgrounds, the treatment and attitude toward money for the employees tend to trigger consumptive behavior, leading to financial problems. In this resarch, the problem will be tested and formulated in the form of research problems, covering from: analyzing mental accounting toward consumptive behavior of the employees; analyzing power-prestige toward consumptive behavior of the employees; analyzing Retention-time toward consumptive behavior of the employees.

\section{Literature Review}

\section{Consumptive Behavior}

Consumptive behavior, according to Sumartono (2002), is a behavior which is not based on rational consideration but because of irrational level desire. According to Dahlan (in Sumartono, 2002), this behavior indicated by luxurious and exaggerate living, using everything considered expensive to satisfy and comfort their physical condition and by the existence of living patterns controlled and motivated by desire to satisfy. Meanwhile, Tambunan (2001), consumptive behavior refers to behavior of the consumers whom uses greater values of money from its production on goods or services in which are not main living needs.

Consumptive behavior is behavior uses greater values of money without rational consideration to get goods in which are not the main living needs and by existence of an assumption that expensive goods will bring satisfaction and physical comfort. Actually, consumptive pattern of an individual is started to form during teenage ages. These ages are ages when someone wants to be acknowledged by the surroundings. According to Mangkunegara (2005), for producers, teenagers are great potential market. It is due to consumptive pattern started to form. Teenagers are also easy to be persuaded in following latest trend, and tend to spend much money.

It is often used by producers to sell products. Especially higher education students, they buy goods in which are not main living needs. It is to get acknowledgement of their presence by buying the latest trending goods or following their favorite idols. Usually, someone will pay more attention on the brands to buy compared to the benefit of the products. According to Sumartono (2002), in buying goods, consumers often consider these things: buying goods because of reward or gift attached, interesting package, keeping appearance and prestige, assumption stating that more expensive goods affecting confidence, trying to use two different products, and buying a product only for having symbolic status. 


\section{Mental Accounting}

According to expected utility theory, the valuse of money are interchangeable, known as fungibility principle. To take decision, money from bonus with amount Rp. 1.000.000,- or coming from salary with amount Rp. 1.000.000,- or money from investment benefit with amount Rp. 1.000.000,- should have same values. One rupiah is one rupiah. No matter where it comes from or what kind of plan to spend it. However, Thaler (1985) in Damayanti and Supramono, observed an individual did not treat the money in the same way (fungible), with the following ilustration: Mr. And Mrs. J have saved \$ 15,000 toward their dream vacation home. They hope to buy the home in five years. The money earns $10 \%$ in a money market account. They just bought a news car for \$11,000 which they finaced with a three-year car loan at $15 \%$.

The couple has labeled the money differently between money to buy house and to buy new car. The incoming money without certain label but someone labels it will cause the values of the money will be different depending on the sources and the purpose. Mr and Mrs $\mathrm{J}$ have money in their saving with additional low interest $(10 \%)$ and then they lent the money by having higher interest, $15 \%$. Then, they get disadvantages and economically it is said not rational. The phenomenon of breaching fungibility principle is know as mental accountig in which is a descriptive theory to explain attitudes of an individual to decide and how a family works in which cannot be explained by classic economy principles. According to Thaler (1980) "mental accounting is the set of cognitive operation use by individual and household to code, catagorize and evaluate financial activities". It assumes an individual explicitly or implicitly have mental accounting system which frequently breaches fungibility principle.

Thaler develops mental accounting theory based on psychological account concept, introduced by Kahneman and Twesky (1979) through prospect theory. The theory integrates psychological variables into financial decision making using psychological account concept to describe how the outcome is evaluated simultaneously or separately. Kahneman and tversky (1984) experimented toward two alternative decissions: A, losing ticket of match with price $\$ 10$, meanwhile, $\mathrm{B}$, loosing money with price $\$ 10$, although $\mathrm{A}$ and $\mathrm{B}$ lose two things with exactly same values, in fact, the realization of decission making are different. $88 \%$ of people losing money will still buy ticket but those losing tickets are $46 \%$ accounted to do the same thing. The explanations are losing ticket and buying the new one is treated in one banking account, while losing money and buying new ticket is done in different account. Therefore, they are evaluated separately. It also shows that mentally, an individual creates spending accounts.

In general context, mental accounting, refers to a process categorizing outcome (Handerson $\&$ Peterson, 1992). The categorization involves noting activities into certain accounts. Mentally, someone tends to label their incomes and outcome and select them into certain accounts. As for example, routine incomes compared to bonus, primary needs compared to joyful needs. Besides that, there is posibility someone will spend the money coming from routine incomes differently compared to from bonus (Thaler, 1990). Incomes gained from efforts (daily or monthly) is percepted to have more values compared to those earned from 
bonus although the amounts are same. It can bring implicaiton to treat the use of incomes differently depended on the sources so it will ease to decide in allocating the incomes. As for example, someone tends to waste their money and act consumptive in spending money gained from bonus because it is considered as a reward.

The phenomenon of other mental accountings is when someone assumes to have already struggle in saving various expense by not buying many htings, but in other side, he cannot save money for certain expense. As for example, to spend money for his hobby although the frequency of buying is relatively seldom but when it is seen from the amount of money spent, it is relatively wasteful. Contrary, someone may save money in certain expenses with huge amount but in other certain expenses will be fewer and meaningless. In fact, when fewer expense is done continously without being aware and is not managed well, it will lead to greater expense accumulation. It will cause him unconciously to whimper, stating he is not prodigals but having difficulties to save money although his income is sufficiently greater.

Shefrin and Thaler (1988), through behavior life-cycle theory grouped assets of wealth into three mental account: current income, current asset, and future income. They predicted someone will spend more when they gained bonus transfered into their current income account instead of their own current asset account, and is spend at least for consumption purpose when it is transfered into future income account. Besides that, the wealth gained at once tends to be stored into current asset. Meanwhile, if it is gained monthly, it will be current income.

Karlsson, Garlin and Selart (1997) proposed hypothesis about doubtness to use saving as predicted by mental accountings will lower when the motivation to save money and consumption are synchronized. There are four motives to save: saving management, keeping alert, finance to create better future, and wealth management. Meanwhile, motive of consumption is differed into: matter to replace something or buy something in which has been really long demanded. As for example of consumption motive is to replace the current goods. The will to spend his saving will be much greater when the motive is to keep alert compared to when his saving motive is to buy a certain good in which has been dreamed a long time ago. Holge and Mason (1995) found empirical evidence that there are some different treatment in using savings depending on the sources. By using experimental approach, the findings show someone tends to spend his saving coming from bonus instead of routine salary.

Thaler (1990) argues why someone uses mental accounting is because it allows transaction evaluated separately from other transactions. It can decrease cognitive burden in deciding and taking decision will be much easier. Chatterjee, Heath, and Min (2009) state mental accounting will negatively impact in decision making. However, Thaler (1999) stated there is no concern whether someone will have rational or irrational mental accountings. Karlson (1988) asserts mental accounting can be used to do self-control. It means preventing any consumptive financial expenses or overspending because the incomes have been grouped into certain accounts and investments in which are not easy to use for other purposes. 


\section{Power-Prestige}

Attitude is defined as feeling to support or to prefer (favorableness) or a feeling not to support or to prefer (unfavorableness) toward a certain object faced. It is triggered by evaluation upon an individual or belief toward certain result gained from cerrtain traits (Hidayat and Nuroho, 2010). Allpot (in Dharmnesta, 1998) sees attitude as a feeling or general evaluation (both positive and negative) toward people, matter of object. Further more, Fishbein and Ajzen (1975) defined attitude as a set of affection felt by someone to accept or deny a certain object or attitude measured by certain procedure to place an individual in two evaluative pollar scales, as for example: good or bad, agree or disagree, and so forth.

Fishbein and Ajzen (1975) differ two kinds of attitudes: (1) attitude toward object in the form of someone's feeling toward things or objects, (2) attitude toward behavior which mostly referring to behavior and not to objects.

In this research, attitude is supportive feeling (positive) or denying feeling (negative) based on overall evaluation of someone toward money (attitude toward objects). This attitude is a negative or positive attitude tendency toward money. Money attitude comes from an individual's experience developed from parents' teaching, experiences upon financial practices in family, in which revised by socializaiton and transaction toward other people.

Yamauchi and Templer (1982) categorize power-prestige first dimension of someone's attitude toward money. In their research, Yamauchi and Templer (1982), show people having higher score of considering money as trading meant to affect and impres other people and as a symbol of success. Besides that, money is seen as meant to gain power upon someone's surrounding and its people. In this dimension, money is considered as dominating meant, meaning money can be used to buy cars, motorbikes, clothes, and so on. According to Walker \& Garmin (1992) in Wong, money is the based of samone to see power in someone else and to be an impressive factor. Meanwhile, according to Csikszentmihalyi \& Rochberg-Halton (1982), quoted by Al - Amoodi (2006), money is asymbol and status for those having it and later those people's existence can be more valueable and acknowledge in their surrounding.

The findings from Durvasula and lysonski (2010) about money attitude toward arrogancy and materialism involves younger consumers in China. From the findings show the impacts of power-prestige toward arrogancy and materialism in younger consumers' in China. Then, in a research about power-prestige, money-attitude is considered negative.

\section{Retention-Time}

Retention - time is second dimension from money attitude (Yamauhci and Templer, 1982). Retention-time refers to attitude to spend money in which needs planning (Yamauchi and Templer, 1982). It is also planning to use money and to buy something (Wong). According to Setyawan (2011), rendition-time is a psychological attitude of someone referring to attitude in which someone does not want to spend all of his money. In spending the money, he will be more careful and it should be planned so it will bring more benefits.

Money attitude as retention-time emphasizes on financial plans carefully in spending the 


\section{Macrothink}

International Journal of Human Resource Studies

ISSN 2162-3058

2018, Vol. 8, No. 4

money. The money is used wisely to buy through initial plans. People with retention-time will struggle to save their financial future (money, assets, and financial security) completely. They manage money through money management, having self-control, satisfaction delaying, saving money, and doing useful consumption. People with retention-time are example of individuals with no tendency to be consumptive shoppers.

Someone with higher score of this factor can be described as people whom place greater values in process of planning and goal of security in the future. They believe money is a source to manage appropriately, so there is a need to plan for the future. The jargon is 'be prepared'. They will be more careful to manage money so they tend to have intention to control themselves in managing their money for personal needs. In other sides, people with lower score of the factor describes future orientation reflection from the upcoming events with little concerns in managing money. It is said they will be more consumptive. Then, in the research, retention-time is money attitude considered positive.

\section{Theoretical Frameworks}

The model used is conceptual framework and also used as theoretical frameworks in this research:

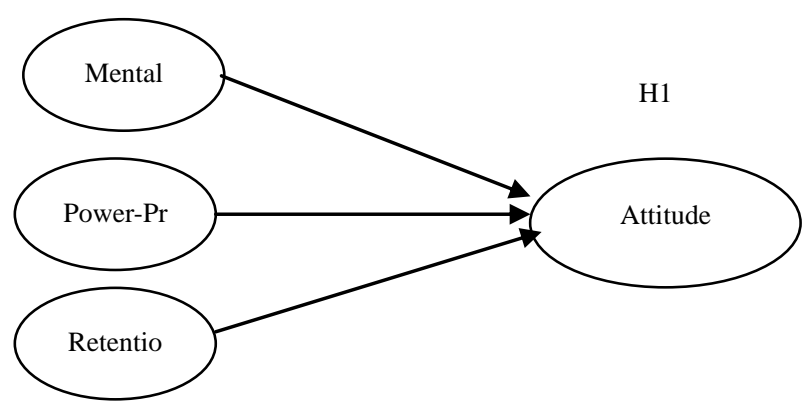

\section{F. Hipotesis}

$H_{1}$ : $\quad$ there is impact of mental accounting toward consumptive behavior

$\mathrm{H}_{2}$ : $\quad$ there is impact of power-prestige toward consumptive behavior.

$H_{3}$ : $\quad$ there is impact of retention-time toward consumptive behavior.

\section{Methodology}

This is a hypothesis testing research to explain phenomena in the form of relationship among variables (Kuncoro, Amin \& Sudarman, 2018). The type of the variable relationship is causailty.

\section{Population and Sample}

The population in this research is Tax Consultant Office, "Handoko Adiprasetyo", Semarang located in Jl. MT. Haryono No. 548 Semarang. Technique of sampling in this research is by cencus to determine the sample by taking all population as sample. The number of samples are 41 people covering from all employees. From 41 samples taken by spreading questionnaires are actually 36 questionnaires return. 


\section{Data Analysis}

Multiple data regression to find out the impact of mental accounting, Power-Prestige and Retention-Time toward consumptive behavior of the employees.

$\mathrm{Y}=\beta_{0}+\beta_{1} \mathrm{X} 1+\beta_{2} \mathrm{X} 2+\beta_{3} \mathrm{X} 3+\mathrm{e}$

Notes :

$\mathrm{X} 1=$ Mental Accounting

$\mathrm{X} 2=$ Power-Pestige

$\mathrm{X} 3=$ Retention-Time

$\mathrm{Y}=$ Consumptive behavior

$\beta_{0} \quad=$ Constanta

$\beta_{1}, \ldots \beta_{3} \quad=$ Regression coefficient

\section{Hypothesis Test}

$\mathrm{H} 0: \mathrm{b} 1, \mathrm{~b} 2, \mathrm{~b} 3=0$ means independent variable partially does not affect positively and is not significant toward the dependent variable.

Ha : $\mathrm{b} 1, \mathrm{~b} 2, \mathrm{~b} 3 \neq 0$ means independent variable partially positively affects and is significant toward the dependent variable.

The criteria of decision making are:

$\mathrm{H} 0$ is accepted if calculated $<$ ttabel on $\alpha=5 \%$

Ha is accepted if calculated $>$ ttabel on $\alpha=5 \%$.

\section{Findings}

\section{Multiple Regression Analysis}

Based on the analysis findings are:

\begin{tabular}{|c|c|c|c|c|}
\hline \multirow{2}{*}{\multicolumn{2}{|c|}{ Model }} & $\begin{array}{c}\text { Standardized } \\
\text { Coefficients }\end{array}$ & \multirow[b]{3}{*}{936} & \multirow[b]{2}{*}{ Sig. } \\
\hline & & \multirow[t]{2}{*}{ Beta } & & \\
\hline \multirow[t]{4}{*}{1} & (Constant) & & & ,356 \\
\hline & Mental_Accounting & ,319 & 2,476 &, 019 \\
\hline & Power_Prestige & ,654 & 5,426 &, 000 \\
\hline & Retention_Time & , 146 & 1,109 &, 276 \\
\hline
\end{tabular}

a. Dependent Variable: Consumptive behavior

Sumber: primary data processed by SPSS 19, 2013

Based on table 4.7, it is gained formula as follows:

$\mathrm{Y}=0,319 \mathrm{X} 1+0,654 \mathrm{X} 2+0,146 \mathrm{X} 3$

In the equation of multiple regression can be explained as follow: 


\section{Macrothink}

International Journal of Human Resource Studies

ISSN 2162-3058 2018, Vol. 8, No. 4

1. The influence of Mental accounting toward consumptive behavior

The score of regression $\mathrm{b}=0,319$, it shows tehre is positive influence from mental accounting variable toward consumptive behavior, $\mathrm{t}=2,476$ dam Sig. $=0,019$ shows significant correlation, so there is positive and significant impact of mental accounting variable toward consumptive behavior.

2. The influence of power-prestige toward consumptive behavior.

Regression score $b=0,654$, it shows tehre is positive influence from power-prestige variable toward consumptive behavior, $, \mathrm{t}=5,426$ and Sig. $=0,000$ shows significant correlation, so it affects positively and significantly toward consumptive behavior.

3. The impact of retention-time toward consumptive behavior.

Regression score, $\mathrm{b}=0,146$, it shows tehre is positive impact from the variable toward consumptive bheavior, $\mathrm{t}=1,109$ and Sig. $=0,276$ shows no significant correlation, so there is no significant influence from the variable toward the behavior.

\section{Partial Significant Test (t-test)}

The t-test of mental accounting, power-prestige, and retention-time influences toward consumptive behaviour uses t-test. It is used to test level of significances of variable $\mathrm{X}$ toward Y. The sample used are 36 employees, so the test uses $\mathrm{T}$ with $\mathrm{dF}=36-2$ or $\mathrm{df}=33$ and level of significant $(\alpha)=5 \%$ then, it is gainedttable $=1,692$. Here are the criteria of the test:

- If tcalculated>ttabel,then variable $\mathrm{X}$ has strong and significant correlation toward $\mathrm{Y}$.

- Iftcaltulated $<$ ttabel,hen variable $X$ does not have strong and significant correlation toward Y.

Here is the following test :

1. $H_{1}$ : there is impact of mental accounting toward consumptive behavior.

From the calculation of t-test for mental accounting resulting tcalculated $=2,476$ is greater than table $=1,692$, so the hypothesis is accepted. Therefore, it can be said there is significant influence of mental accounting toward consumptive behavior of the employees.

2. $\mathrm{H}_{2}$ : there is impact of power-prestige toward consumptive behavior.

The calculation of power-prestige resultstcalculated=5,426greater than the score oft table $=1,692$, so the hypothesis is accepted. Therefore, it can be said there is significant influence of power-prestige toward consumptive behavior of the employees.

3. $\mathrm{H}_{3}$ : There is impact of retention-time toward consumptive behavior.

The calculation of retention-timeresultstcalculated $=1,109$ smaller than table $=1,692$ so the hypothesis is denied. Therefore, it can be said there is no significant retention-time toward the behavior of the employees. 


\section{Simultant Test (F-test)}

This test has purpose to find out whether there is significant influences simultaneously among independent variables toward the dependent variable. From the satistic data calculation, it shows the results of F-test resulting $F_{\text {calculated }}=13$,93is greater than $F_{\text {table }}=2,84$. Therefore, it can be concluded mental accounting, power-prestige, and retention-time significantly influence consumptive behaviour of the employees.

\section{Discussion}

\section{The influence of mental accounting toward consumptive behavior}

The first hypothesis states there is influence of mental accounting toward consumptive behavior of the employees. The results of the test support the first hypothesis and the impact is considered as positive and significant. It means the higher mental accounting will affect on higher consumptive behavior. The test aligns with study done by Chatterjee, Heath, and Min (2009), and Thaler (1990) considering mental accounting can bring inappropriate impacts in financial deciding because there is possibility to be wasteful or act consumptive upon extra earnings.

Most of the employees are young females aged 20 - 29 years old with lower earnings. They have mental accounting with tendency to group the source of their incomes and the purposes. It is caused because of their lower earnings or salary so they need to be careful in spending their money by grouping them and setting some purposes. However, because they are young ladies whom usually want to appear beautifully, then it is possible to consider them selves that their salaries are more valuable compared to extra earnings or bonus. It causes they tend to be more consumptive when they get bonus or extra earnings. They do not save their bonus money with reason it is additional bonus or reward in which is considered to have different values to their monthly salaries.

This finding does not align with study done by Karlsson (1998), Moch and Loewenstein (1991), Damayanti and Supramono (2011) whom state mental accounting attitude can be used as self-control.

Generally, mental accounting can motivate someone to act consumptively in managing his own money. Someone acts so is caused by carelessness in allocating his extra income into his needs and savings. It also means that someone with mental accounting does not always have well planning in managing money so bonus or extra incomes can be used for their short neccessities.

\section{The Influence of power-prestige toward consumptive behavior}

Second hypothesis states power-prestige influences the behavior of the employees. From the test, the findings support the second hypothesis and the influences are addressed are considered positive and significant. It means the higher power-prestige will result higher consumptive behavior.

Most of the employees are young females whom usually tend to expose them selves by 
appearing beautifully. When someone with power-prestige has money, she will struggle to show her existence to get acknowledgement. It also causes different treatment toward money. They will judge money to have important role to get external acknowledgement from surroundings, social status, or domination upon other people and finally it is seen as symbols of status and success. Besides that, money is seen as meant to gain power upon soneone's environment and people surrounding. An individual with higher power-prestige will spend money to improve her social and economical status and to impress other people. Therefore, this attitude tends to be consumptive in managing money.

From the hypothesis, there is influence of power-prestige toward consumptive behavior. It aligns with findings by Csikszentmihalyi \& Rochberg-Halton (1981), quoted in Al - Amoodi (2006) stating that money is a symbol and status for someone has it. Then, the existence of the person will be more valuable in his surrounding so sometimes it leads to consumptive behavior in spending money to buy luxurious goods withouth considering their benefits.

\section{The influences of retention-time toward consumptive behavior}

Third hypothesis states retention-time toward consumptive behavior of the employees. From the test, the findings do not support the hypothesis. Therefore, retention-time does not significantly affect consumptive behavior.

Retention-time describes the use of money directed for financial planning purposes. People with such attitude will be more careful in spending money and more aware about financial condidition. They spend money carefully through planning so they are considered not to be consumptive. They manage money through financial maangement, self-control, satisfaction delay, saving useful consumption. It shows they have everything in the future and believe money is source to manage well.

Statistic descriptive analysis about retention-time shows that the employees have sufficiently higher score. It means they have tendency to act retention-time toward money. They carefully manage the mnoney and assume money is the source to manage. Thus, retention-time of the employees should negatively affect toward consumptive behavior. But, in this research it has positive affect, not being significant toward consumptive behavior. It is due to most of the employees are young women who want to beautifully appear by having branded goods. They are easily tempted by interesting advertisement. In the beginning, they have had plan to managae their money well. But because of their desire, they are faced to interesting advertisement and products in which frequently tempted and their plans do not work consistently.

In this hypothesis, it does not align with Setyawan's study (2011). Retention-time does not influence consumptive behavior so the students tend not to be consumptive.

\section{Determination Coefficient (R2)}

From the analysis, it shows the result of f-test: Fcalculation=13,93is greater thanFtable $=2,84$. Therefore, it can be concluded that mental accounting, power-prestige, and retention-time influence significantly toward consumptive behavior of the employees. 


\section{Ml Macrothink}

International Journal of Human Resource Studies

ISSN 2162-3058

2018, Vol. 8, No. 4

From quantitative analysis also shows determination coefficient (R-square) used to find out affective percentage of independent variable $\left(\mathrm{X}_{1}, \mathrm{X}_{2}\right.$, danX $\left.\mathrm{X}_{3}\right)$ toward dependent variable $(\mathrm{Y})$ is 0,566. It means consumptive behavior is affected by mental accounting, power-prestige, and retention-time with percentage $56.6 \%$. The rest, $43.4 \%$ is affected by external factors of the study. Those factors are assumed to be incomes and the personalities of the employees.

\section{Conclusion}

Based on the findings, the conclusions are:

1. There is significant influence of mental accounting toward consumptive behavior of the employees when they tend to group their money based on their sources and purposes. They assume that salary earned monthly has more values compared to bonus or extra earning. By considering bonus or extra earning are easily to get money, then they tend to spend it without planning. It causes consumptive behavior.

2. There is significant influences of power-prestige toward consumptive behavior of the employees when they treat the money will have important role to get acknowledgement from other parties. Money is seen as symbol of status and success. They spend money to improve their economy position and social status. They impress other people in which will cause consumptive behavior in managing personal money.

3. There is no significant influences of retention-time toward consumptive behavior of the employees. They are careful to spend money and consider money is a source to manage well. However, retention-time is not done consistently so it influences toward consumptive behavior although not significant.

\section{Implication}

\section{Theoretical Implicaiton}

The findings show there is significant mental accounting influences toward consumptive behavior. Therefore, this research supports the findings of Chatterjee, Heath, and Min (2009), and Thaler (1990) assuming mental accounting will negatively influence financial decision making because there is possibility to spend more and to consumptively behave upon their extra earning. However, it does not align with research done by Karlsson (1998), Moch and Loewenstein (1992), and Damayanti and Supramono (2011) stating mental accounting can be used as self-control.

Power-prestige also significantly influences consumptive behavior of the employees. The findings align with Csikszentmihalyi \& Rochberg-Halton (1981) quoted by Al - Amoodi (2006) stating that money is symbol and status for those having it. And it will finally create someone's existence in the environment more acknowledged and leads into consumptive behavior.

Retention-time positively influence but not significant toward consumptive behavior of the employees. The findings do not align with Setyawan (2011) stating retention-time does not influence consumptive behavior. They are careful to spend money and assume money is 
source to manage well. However, it is not done consistently. So, retention-time attitude of the employees positively influences consumptive behavior although not significant.

From the conclusion, there are several things to suggest in their implication:

1. The employees tend to act mental accounting by grouping the source of incomes and the purpose in which significantly affect consumptive behavior. To overcome, it needs to be wise by assuming salary is not always located in certain groups and is more valuable compared to bonus. So, the ways to spend money is not based on interesting products without consideration but also the benefits of the product.

2. Power-prestige significantly affects toward consumptive behavior. To overcome this condition, there is a need to treat money wisely. It is not by seeing money as symbol of success and repected. Therefore, there will be no need to compete in spending money to be respected but to spend money in productive goods.

3. Retention-time influences positively but not significant toward consumptive behavior. The employees seem to be careful in spending money and considered money as source to manage but it s not done consistently. Thhus, there is a need of consistency in managing money and considering rationally the benefits of buying goods to avoid any consumptive behavioral tendencies.

\section{Research Limitation}

The researchers realize there are still many weaknesses in composing the research started from no personality type variable included and the amount of salary in which can be affective variable toward consumptive behavior. For the further researchers, there is a need of retesting by adding some uninvestigated variables yet.

\section{References}

Al-Amoodi, M., \& Abdulrhman, S. (2006). Exploring Money Attitudes And Credit Carid Usage In Compulsive Buying Among (Mba) Executive Students (USM) (Doctoral dissertation, USM).

Chatterjee, S., Heath, T. B., \& Min, J. (2009). The susceptibility of mental accounting principles to evaluation mode effects. Journal of Behavioral Decision Making, 22(2), 120-137. https://doi.org/10.1002/bdm.616

Ghozali, I. (2006). Aplikasi analisis multivariate dengan program SPSS. Badan Penerbit Universitas Diponegoro.

Handerson, P., \& Peterson, P. (1992). Mental Accounting and categorization. Organizayional Behavior and human Decision Processes, 51, 92-177. https://doi.org/10.1016/0749-5978(92)90006-S

Hodge, S. K., \& Mason, C. H. (1995). Work versus windfall: An exploration of saving on subsequent purchase. Marketing Letters, 6(2), 91-100. https://doi.org/10.1007/BF00994925

Kahneman, D., \& Tvesrky, A. (1979). Choice, values, and frames. American Psykologist, 39, 
341-350. https://doi.org/10.1037/0003-066X.39.4.341

Kamleitner, B., Hoelzl, E., \& Kirchler, E. (2012). Credit use: Psychological perspectives on a multifaceted phenomenon. International Journal of Psychology, 47(1), 1-27. https://doi.org/10.1080/00207594.2011.628674

Kholila. (2008). Perilaku Konsumtif Pada Masyarakat Pengunjung Pasar Kaget di Wisata Belanja Tugu Gajayana Malang. Malang: Skripsi FakultasPsikologi Universitas Islam Negeri Maulana Malik Ibrahim Malang.

Kotler, P. S. H. (2000). Managemen Pemasaran Persepektif Asia. Yogyakarta: ANDI.

Kuncoro, A. D. S. (2018). Metode Penelitian Manajemen. Andy, Yogyakarta.

Mangkunegara, A. P. (2005). Perilaku Konsumen. Bandung : PT. Refika Aditama.

PUSPITA, D. D., \& Meiyanto, I. S. (2009). Hubungan antara nilai materialisme dan sikap terhadap uang dengan perilaku konsumptif pada wanita pengguna kartu kredit (Doctoral dissertation, Universitas Gadjah Mada).

Roberts, J. A., \& Jones, E. (2001). Money attitudes, credit card use, and compulsive buying among American college students. Journal of consumer affairs, 35(2), 213-240. https://doi.org/10.1111/j.1745-6606.2001.tb00111.x

Setyawan, W. (2011). Pengaruh Literasi Keuangan, Variabel Demografi, dan Money Attitude Scale (MAS) terhadap Perilaku Penggunaan ATM pada Mahasiswa. Skripsi tidak diterbitkan. Program S1 Fakultas Ekonomika dan Bisnis Universitas Kristen Satya Wacana.

Shefrin, H. M., \& Thaler, R. H. (1988). The behavioral life-cycle hypothesis. Economic inquiry, 26(4), 609-643. https://doi.org/10.1111/j.1465-7295.1988.tb01520.x

Sugiyono. (2007). Metode Penelitian Bisnis, Alfabeta, Bandung.

Sumartono. (2002). Terperangkap Dalam Iklan, Alfabeta, Bandung.

Supramono, dkk, (2010). Desain Penelitian Keuangan Berbasis Perilaku, Pusat Studi Keuangan Berbasis Perilaku, Fakultas Ekonomi dan Bisnis, UKSW.

Tambunan, Raymond, Psi. (2001). Remaja dan perilaku Konsumtif. Available FTP: http://www.google.com/search?q=duniaesai.com/psikologi/psi3.htm+perila u+konsumtif+remaja\&hl=id\&ct=clnk\&cd=1\&gl=id. Tanggal akses. 22 Februari 2007

Thaler, R. (1980). Toward a positive theory of consumer choice. Journal of Economic Behavior \& Organization, 1(1), 39-60. https://doi.org/10.1016/0167-2681(80)90051-7

Thaler, R. (1985). Mental accounting and consumer choice. Marketing science, 4(3), 199-214. https://doi.org/10.1287/mksc.4.3.199

Thaler, R. H. (1990). Anomalies: Saving, fungibility, and mental accounts. Journal of economic perspectives, 4(1), 193-205. https://doi.org/10.1257/jep.4.1.193

Theresia, W. D. dan S. (2011). Realitas Mental Accounting: Studi Pada Perlakukan 
Pendapatan Ekstra, Manajemen Usahawan Indonesia, 40(2).

Wong, J. (2010). An analysis of money attitudes: Their relationships \& effects on personal needs, social identity and emotions. Journal of Leadership, Accountability and Ethics, 8(1), 57-64.

Yamauchi, K. T., \& Templer, D. J. (1982). The development of a money attitude scale. Journal of personality assessment, 46(5), 522-528. https://doi.org/10.1207/s15327752jpa4605_14

\section{Copyright Disclaimer}

Copyright for this article is retained by the author(s), with first publication rights granted to the journal.

This is an open-access article distributed under the terms and conditions of the Creative Commons Attribution license (http://creativecommons.org/licenses/by/4.0/). 